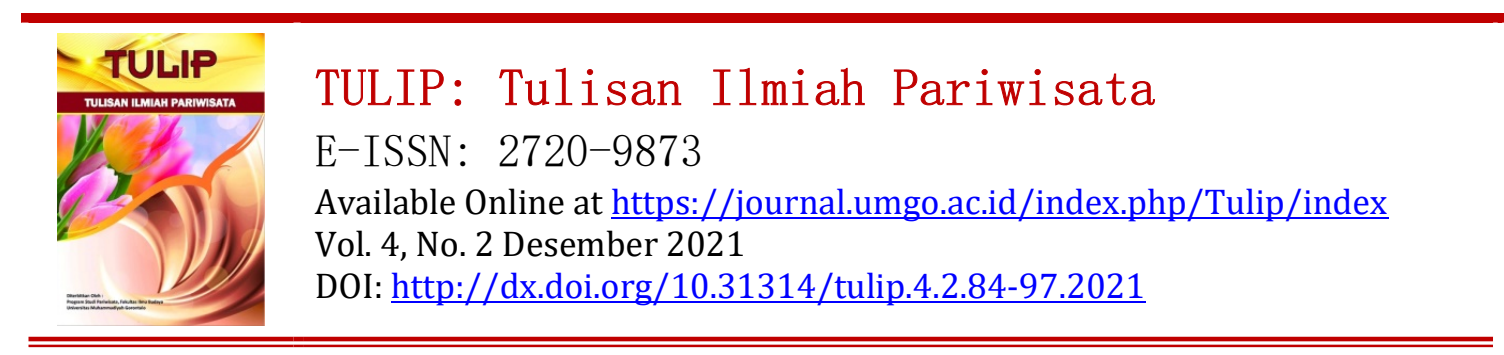

\title{
ANALISIS STRATEGI BAURAN PROMOSI DAN STRATEGI SALURAN DISTRIBUSI PADA UNIT KELOLA ARCHIPELAGO INTERNATIONAL PADA SITUASI PANDEMI COVID-19 KOTA DENPASAR, BALI
}

Fadillah Manuhutu' ${ }^{1}$ Ida Ayu Putri Widawati ${ }^{2}$, Amirosa Ria Satiadji ${ }^{3}$.

1,2,3,. Magister Terapan Pariwisata, Politeknik Pariwisata Bali, Indonesia

Email;1.Fadillah.manuhutu@gmail.com,putri7widawati@gmail.com, amirosaria@gmail.com

Info Artikel Abstract:

The objectives of this study are (1) to analyze the marketing promotion strategy

Diterima: 20of hotel products carried out by Aston Denpasar, Neo Denpasar, Quest Denpasar

11- 2021 during the covid-19 pandemic, (2) to analyze the marketing distribution channel strategy carried out by Aston Denpasar, Neo Denpasar, Quest Denpasar

Disetujui: 02during the covid-19 pandemic, (3) To determine the right promotion strategy $12-2021$ and distribution channel strategy during the covid 19 pandemic. This research uses qualitative research. Data analysis uses SWOT analysis where SWOT analysis is a tool used to compile the company's strategic factors. The results of

Publish: 0201-2022 this study. (1) The strategy used three hotels is to carry out the same promotional mix, namely personal selling, advertising, sales promotion and publicity strategies. (2) The distribution channel strategy carried out by Aston Denpasar, Neo Denpasar and Quest Hotels is where the hotel determines the best distribution channel for its products to meet customer needs. Consumer needs used direct distribution and distribution through wholesale agents. (3) The marketing and distribution mix recommendation strategy through swot analysis is in a growth strategy through horizontal integration.

Keywords: Promotion Mix, SWOT Analysis, Distribution Channels, Covid 19 Pandemic

\begin{abstract}
Abstrak:
Tujuan dari penelitian ini adalah (1) Menganalisis stretegi promosi pemasaran produk hotel yang dilakukan oleh Aston Denpasar, Neo Denpasar, Quest Denpasar dimasa pandemi covid- 19, (2) Menganalisis strategi saluran distribusi pemasaran yang dilakukan oleh Aston Denpasar, Neo Denpasar, Quest Denpasar dimasa pandemi covid-19, (3) Untuk menentukan strategi promosi dan strategi saluran distribusi yang tepat dimasa pandemi covid 19. Penelitian ini menggunakan jenis penelitian kualitatif. Analisis data yang digunakan dalam penelitian ini adalah Analisis SWOT dimana Analisis SWOT merupakan alat yang dipakai untuk menyusun faktor faktor strategis perusahaan. Hasil penelitian (1) Strategi yang digunakan pada ketiga hotel tersebut adalah melakukan bauran promosi yang sama yaitu melakukan strategi personal Selling, periklanan, promosi penjualan dan publisitas. (2) Strategi saluran distribusi yang dilakukan oleh Hotel Aston Denpasar, Neo Denpasar dan Quest Hotel adalah dimana hotel tersebut menentukan jalur distribusi terbaik untuk produk produknya guna memenuhi kebutuhan konsumen, diantaranya menggunakan distribusi
\end{abstract}


langsung dan distribusi melalui Wholesale agent. (3) Strategi rekomendasi bauran pemasaran dan distribusi melalui analisis swot yaitu berada pada strategi pertumbuhan melalui integrasi horizontal.

Kata Kunci: Bauran Promosi, Analisis SWOT, Saluran Distribusi, Pandemi Covid 19

\section{PENDAHULUAN}

Pada era globalisasi perdagangan

adalah aktivitas pemasaran memegang peranan yang sangat penting bagi perusahaan. Manajemen pemasaran sebagai seni dan ilmu dalam memilih pasar, mendapatkan, mempertahankan, dan mengembangkan pelanggan, penyampaian, dan komunikasi nilai pelanggan yang unggul. Untuk menjadi pemasar, perlu dipahami apakah itu pemasaran, bagaimana cara kerjanya, siapa yang melakukannya, dan apa yang dipasarkan. Kegiatan pemasaran perusahaan dimulai dengan mengidentifikasi kebutuhan konsumen. Identifikasi kebutuhan konsumen dilakukan oleh setiap hotel dengan cara menyusun konsep strategi yaitu segmentasi pasar, market positioning, market entry strategy, marketing mix strategy, timing strategy.

Bauran pemasaran (marketing mix) adalah sebuah alat pemasaran yang digunakan oleh perusahaan, dimana perusahaan mengendalikannya dan mempengaruhi respon pasar sasaran. Dalam bauran pemasaran terdapat seperangkat alat pemasaran yang dikenal dengan istilah $4 \mathrm{P}$, yaitu product, price, place, dan promotion, sedangkan dalam pemasaran jasa terdapat beberapa alat pemasaran tambahan seperti people, phisycal evidence, dan process. Dari
4P bauran pemasaran, penelitian ini fokus pada promotion dan place. Promosi hotel adalah hal yang sangat menentukan keberadaan sebuah hotel dalam menarik minat konsumen. Promosi yang dilakukan dimasa pandemi covid-19 adalah hal yang paling menantang bagi Industri perhotelan. Dimana kondisi external wabah penyakit covid-19 telah melanda Industri perhotelan dan membuat tujuan wisata di seluruh Indonesia sepi oleh pengunjung.

Bisnis akomodasi hotel dan restoran tengah berjuang keras di tengah pandemi. Para pelaku usaha harus bisa berinovasi untuk bisa bertahan. Sektor pariwisata bergantung pada kebijakan pemerintah, terutama di tengah pandemi covid-19. Situasi pandemi membuat operasional sektor pariwisata termasuk hotel dan restoran terdampak dalam menjalankan bisnisnya. Hotel tidak bisa berdiri sendiri, bergantung pada kebijakan pemerintah karena pergerakan orang dibatasi dalam melakukan perjalanan liburan dan perjalanan bisnis. Tantangan saat ini adalah perusahaan harus pemilihan place yang tepat untuk perusahaanya, dimana penempatan yang benar adalah aktivitas vital yang terfokus pada konsumen yang tepat dan di waktu yang tepat. Dalam hal ini perusahaan menentukan strategi 
saluran distribusi tentang proses produk bisa sampai dengan baik kepada konsumen.

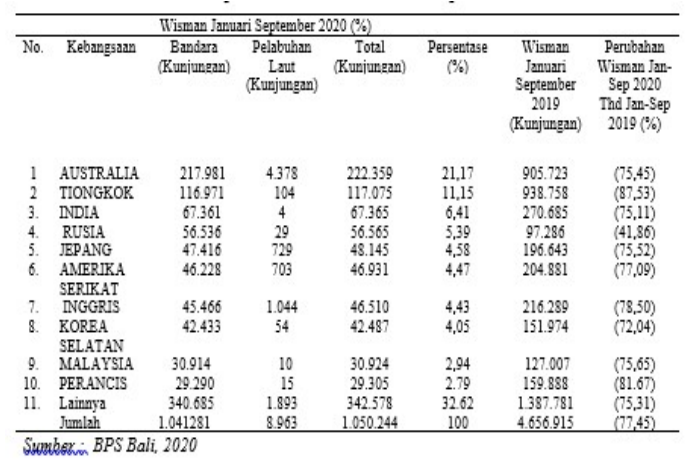

Tabel 1: 10 Negara Utama Kedatangan Wisman Menurut Kebangsaan Januari September 2019 dan Januari - September 2020 di Bali

Periode Januari-September 2020, kunjungan wisman ke Bali tercatat sebanyak 1.050.244 kunjungan. Jumlah ini turun seebesar $-77,45$ persen dibandingkan dengan capaian periode Januari-September 2019 (y on y) yang tercatat sebanyak 4.656.915 kunjungan. Kalau diurutkan berdasarkan production terhadap total secara kumulatif, maka wisman kebangsaan Australia tercatat sebagai wisman dengan sumbangan terbesar yaitu 21,17 persen, kemudian disusul dengan urutan berikutnya wisman kebangsaan Tiongkok $(11,15$ persen), India (6,41 persen), Rusia (5,39 persen), Jepang (4,58 persen), Amerika Serikat (4,47 persen), Inggris (4,43 persen), Korea Selatan (4,05 persen), Malaysia $(2,94$ persen), dan Perancis (2,79 persen). Dari sepuluh kebangsaan wisman selama periode Januari - September 2020, jika diurai menurut besarnya perubahan dibandingkan periode yang sama tahun sebelumnya, maka wisman berkebangsaan Tiongkok tercatat mengalami penurunan paling besar yaitu sebesar -87,53 persen, disusul oleh Perancis $-81,67$ persen, dan wisman berkebangsaan Inggris sedalam $\quad-78,50$ persen. Selengkapnya rincian kedatangan wisman menurut kebangsaan secara kumulatif disajikan pada tabel 1 diatas.

Bali sebagai destinasi pariwisata mengalami dampak paling besar dari sisi ekonomi dan peneyebaran covid-19. Tingkat hunian hotel secara keseluruhan diperkirakan turun ke 30-40\% sejak awal Januari dan zero occupancy dimasa pandemi. Data PHRI menyebutkan pada April lalu bahwa 698 hotel di seluruh Indonesia telah ditutup karena Pandemi covid-19. Pada bulan September 2020, Tingkat Penghunian Kamar (TPK) hotel berbintang di Bali tercatat sebesar 5,28 persen, naik setinggi 1,60 poin (month to month) dibandingkan dengan TPK pada bulan Agustus 2020 yang mencapai 3,68 persen. Jika dibandingkan dengan TPK bulan September 2019 (year on year) yang tercatat sebesar 63,22 persen, TPK bulan September 2020 tercatat turun sedalam $-57,94$ poin. Data tersebut dapat dilihat pada tabel berikut:

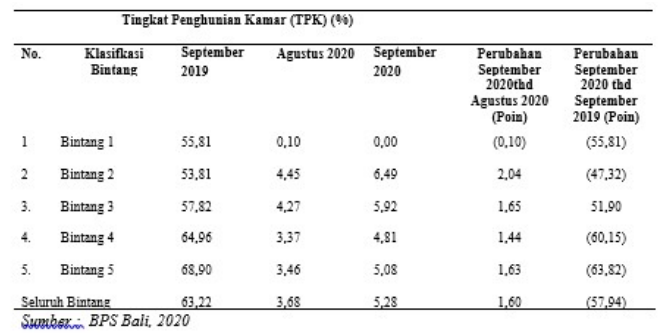

Tabel 2: Tingkat Penghunian Kamar (TPK) Hotel Berbintang di Bali 
Hampir seluruh wisatawan dari negara yang dikenal sebagai pasar wisata utama Indonesia seperti China, Malaysia, Singapura dan Australia turun di bulan Februari hingga September, apalagi diberlakukanya penutupan pintu masuk transportasi oleh beberapa Negara di Dunia. Kunjungan wisatawan dari China sendiri turun 93,5 persen menjadi hanya 11.780 orang pada Februari1 dari 199.960 wisatawan pada periode yang sama tahun lalu. Dampak pandemi covid-19 ini yaitu Penurunan penjualan sebesar $90 \%$ menyusul pembatalan pemesanan pada bulan Maret dengan potensi kerugian diperkirakan mencapai $\mathrm{Rp} \quad 4$ triliun, kontrak kerja sebagian besar pekerja tidak tetap tidak diperpanjang. Pekerja Harian harus kehilangan pekerjaan selama masa pendemi covid-19. Perusahaan kesulitan untuk membayar biaya operasional dan gaji pada bulan Februari dan Maret. Sektor pariwisata dan bisnis pada masa pandemi covid-19, melakukan beberapa tindakan standar protokol yaitu seperti disinfektan pada area destinasi pariwisata dan hotel, agar mengurangi dampak ketidakpercayaan wisatawan selama di Indonesia. Kedua melakukan sertifikasi CHSE. Ketiga Mengaplikasikan aturan kesehatan dilingkungan kerja dengan ketat, Keempat standar pemeriksaan tamu yang memasuki area hotel baik dokumen kesehatan dan kondisi fisik tamu.
Archipelago International adalah operator hotel swasta dan mandiri terbesar di Asia Tenggara. Archipelago International telah menjadi pemimpin pasar di Bali, yang merupakan salah satu tujuan perjalanan paling populer di dunia. Archipelago International Indonesia merupakan perusahaan manajemen hotel terdepan di Indonesia. Pada tahun 1997, Charles Brookfield selaku pendiri dari Archipelago International Indonesia memulai usahanya dengan visi untuk membawa perubahan di industri perhotelan. Dalam 20 tahun terakhir, Archipelago mengubah visi tersebut menjadi kenyataan, Archipelago International Office menjadi pionir konsep kondotel pertama, memprakarsai "ledakan" hotel bujet. Dimulai hanya dengan 3 hotel, ekspansi Archipelago berkembang secara pesat dan belum pernah terjadi sebelumnya, dengan dibukanya 1 hotel setiap 2 minggu selama bertahun-tahun hingga hari ini, dimana mereka kini merupakan salah satu dari 100 jaringan hotel terbaik di dunia, dengan portofolio hingga 127 hotel yang terbagi dalam 7 brand: favehotel, NEO, Quest, Harper, Aston, Alana and Kamuela.

Kamar adalah produk akomodasi utama industri perhotelan. Pengaruh tingkat hunian kamar merupakan tolak ukur keberhasilan dari sebuah hotel. Tingginya tingkat hunian kamar sebuah hotel secara tidak langsung akan mempengaruhi penghasilan dan profitabilitas dengan demikian setiap perusahaan akan selalu 
berusaha meningkatkan profitabilitas, karena semakin tinggi tingkat profitabilitas suatu perusahaan maka kelangsungan hidup perusahaan tersebut akan lebih terjamin.

Dalam penelitian ini strategi bauran promosi dan strategi distribusi channel fokus mengambil di unit kelola Archipelago International yaitu Hotel Aston Denpasar, Hotel Neo Denpasar dan Hotel Quest Denpasar. Hotel Aston Denpasar berdiri pada Tahun 2008. Jumlah kamar 258 Rooms. Jenis kamar tediri dari Studio Rooms 30 units, One bedrooms Suites 137 Units dan Two bedrooms Apartement 91 Units. Konsep Hotel pada awalnya adalah Hotel yang terintegarasi dengan Mall di Area Gatot Subroto barat. Fasilitas yang tersedia di Hotel Aston Denpasar adalah Jempiring restaurant dengan konsep Makanan nusantara, chinese food dan western food. Kemudian terdapat 14 function rooms yaitu Grand Ballrooms (1270 m2), Agung (200 m2), Batukaru (200 m2), Abang (100 m2), Batur 1 (173 m2), Batur 2 (173 m2), Catur (161 m2), Silangjana 1 (159 m2), Silangjana 2 (159 m2), Pohang 1 (112 m2) dan Pohang 2 (112 m2). Dan terdapat tiga Swimming pools di area hotel.

Hotel Aston Denpasar memiliki konsep dengan jumlah kamar yang besar dan tempat meeting yang banyak jumlahnya. Sebagai pilihan yang tepat bagi corporate dan government untuk melakukan kegiatan Meeting, Incentive, Convention and Exhibithion. Berada di pusat kota, bisnis dan pemerintahan menjadikan hotel ini ideal untuk bertahan dan bersaing dimasa pandemi covid-19. Saat ini jika hotel lain dibali baru melirik pasar lokal, maka Hotel Aston denpasar telah duluan menjadikan pasar lokal sebagai pasar utama dalam menawarkan produk hotel yang mengikuti demand saat ini serta flexibility pasar yang semakin bersaing dalam memperebutkan pasar di denpasar. Dimasa pandemi covid-19 kita harus mampu memberikan pilihan aman dan sehat dalam menawarkarkan produk makanan salah satu yang dilakukan saat betahan dimasa pandemi adalah delivery meals box dan Drive Thru services.

Segmentasi tamu Hotel Aston Denpasar adalah Government, Company Swasta dan Badan usaha milik negara, China Group, dan Social Event. Tamu yang paling mendominasi adalah tamu Government dan China. Sebelum masa pandemi covid-19 tingkat hunian mampu memberikan hasil yang memuaskan. Dapat dilihat pada tabel tersebut

Tabel 3: Tingkat Hunian Kamar Hotel Aston Denpasar Sebelum Pandemi Covid-19 20142019

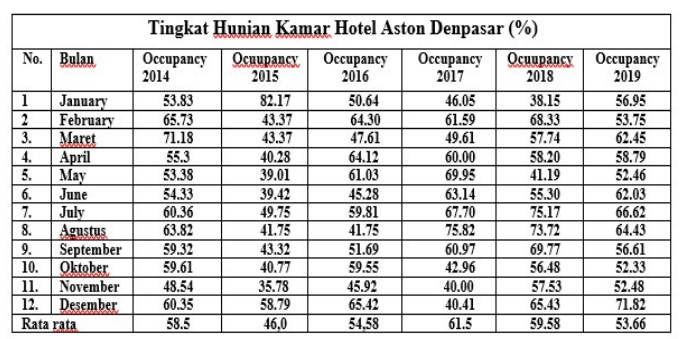

Sumber : Data Hotel Aston, 2020 
Dari data diatas menunjukkan bahwa Hotel Aston denpasar sebelum pandemi covid 19 masih mampu bertahan dalam pembiayaan operasional bahkan mampu memberikan Margin bagi perusahaan. Seperti kita ketahui di Tahun 2018 adalah masa kondisi external bali mengalami letusan gunung agung dengan status beberapa Negara memberikan travel warning pada warganya. Namun kondisi tersebut tidak membuat Hotel Aston Denpasar sampai mengalami resiko penutupan hotel. Jika dibandingkan data pada masa pandemi covid-19 pada tabel 1.4 Data Occupancy Hotel Aston Denpasar masa pandemi covid-19 memberikan hasil yang tidak memuaskan bagi perusahaan.

Sedangkan pada masa pandemi covid 19 menunjukkan bagaimana Hotel Aston Denpasar mampu bertahan dimasa pandemi covid-19 dengan bantuan suntikan dana owner January-June. Prediksi Bulan Juli oleh bagian pemasaran adalah hotel harus sudah ditutup, dikarenakan kondisi pasar yang tidak menentu. Serta tidak ada aktivitas apapun yang boleh dilakukan saat itu. Namun bersama manajemen menyusun rencana mitigasi untuk perusahaan. Pada Bulan Juli-Oktober Hotel ini masih mampu bertahan dan berhasil BEP dibulan Agustus. Hotel Neo Denpasar adalah hotel kedua dalam penelitian ini, lokasi yang ideal untuk memulai perjalanan Anda ke Art Center artistik, Monumen Bajra Sandhi dan Pura Jagatnatha. Terletak hanya 45 menit dari
Bandara Internasional Ngurah Rai, hotel ini berada di tengah menikmati apa yang ditawarkan Denpasar Bali. 112 kamar tamu di 5 lantai memastikan kami memiliki ruang yang cukup untuk semua kelompok dan tim yang bersemangat untuk melayani semua tamu kami. Hotel Neo Denpasar dilengkapi dengan 4 ruang pertemuan, menampung hingga 400 tamu dalam konferensi bergaya teater besar atau dalam sesi ruang rapat kecil. Semua ruang pertemuan ber-ac dan dilengkapi dengan sound system, papan tulis, proyektor dan layar lcd, ditambah akses internet wi-fi berkecepatan tinggi. Hotel Neo Denpasar dengan berbagai fasilitas kami termasuk kolam renang luar ruangan dan ruang kesehatan. Segmentasi Hotel Neo Denpasar adalah Government, China Group, dan Social Event. Tamu yang paling mendominasi adalah tamu Social event dan China.

Penulis melihat occupancy kamar yang mampu bersaing ditengah pandemi covid 19. Berada diposisi kedua dalam kompetisi setelah Hotel Quest Denpasar yaitu $35 \%$. Penelitian selanjutnya dilakukan di Hotel Quest Denpasar salah satu hotel yang bertahan dimasa pandemi covid-19. Tentu saja hotel ini mendapatkan suntikan dana diawal masa pandemi covid-19, namun mampu bangkit dan mempertahankan posisi Agustus-Oktober tetap bertahan pada urutan pertama dikompetisi hotel.

Hotel Quest Denpasar Terletak di Pusat Kota Denpasar, hotel ini menawarkan 
kamar suite, bersih dan nyaman yang dirancang secara imajinatif dengan kecanggihan modern dan suasana kontemporer. Hotel Quest Denpasar ramah dan praktis, menawarkan kombinasi gaya dan fungsi yang luar biasa dilengkapi untuk liburan yang mewah, tetapi lengkap dan menyenangkan bagi wisatawan. Setiap kamar dilengkapi dengan perabotan kontemporer yang apik, Tv layar datar, minibar, dan akses Wi-Fi berkecepatan tinggi. Restaurant Bhira dengan menu Bali Merupakan pilihan pertemuan atau acara khusus untuk kelas bintang tiga. Ballroom yang luas dapat menampung hingga 300 orang, Ideal untuk acara perayaan apa pun. Memiliki 5 ruang pertemuan tambahan. Segmentasi Hotel Quest Denpasar adalah Government, Company Swasta dan Badan usaha milik negara, China Group, dan Social Event. Tamu yang paling mendominasi adalah tamu Government dan China. kunjungan wisatawan dibali diatas menunjukkan bahwa wisatawan nusantara masih berpotensi market dibali selama pandemi covid 19, terkoreksi minus 50 persen atau ada sekitar 4.596.157. Namun dengan market yang masih ada terjadi kompetisi hotel yang sangat ketat dari sisi harga sedangkan ketersediaan kamar dibali masih tetap dibandingkan dengan jumlah turis yang dating, terjadi ketimpangan antara demand dan Supply. Dalam hal ini diperlukan strategi bauran promosi dan saluran distribusi channel yang tepat untuk memenangkan market yang masih ada. Kebijakan manajemen sangat berpengaruh dimasa pandemi covid-19 khususnya pada kebijakan pemasaran dalam menarik minat wisatawan lokal untuk memilih hotel Archipelago international dibandingkan hotel group lain. Merujuk pada uraian tersebut maka penulis mengangkat judul Analisis Strategi bauran promosi dan Strategi saluran distribusi pada unit kelola Archipelago International pada situasi pandemi covid-19 Kota Denpasar, Bali.

\section{METODE PENELITIAN}

Penelitian ini menggunakan jenis penelitian kualitatif, dengan teknik pengumpulan data menggunakan observasi, wawancara, studi kepustakaan dan dokumentasi. Analisis data yang digunakan dalam penelitian ini adalah Analisis deskriptif kualitatif. Analisis deskriptif adalah analisis data yang tidak berbentuk angka, tetapi berupa serangkaian informasi yang digali dari hasil penelitian tetapi masih merupakan data-data yang verbal atau masih dalam keterangan-keterangan saja. Data tersebut mempunyai peran untuk menjelaskan secara deskriptif suatu masalah. Dalam hal ini dengan cara memaparkan informasi-informasi akurat yang diperoleh dari Hotel Aston Denpasar, Neo Denpasar, Quest Denpasar dan analisis SWOT dimana Analisis SWOT merupakan alat yang dipakai untuk menyusun faktor faktor strategis perusahaan. Dimana SWOT ini dapat 
menggambarkan secara jelas bagaimana peluang dan ancaman eksternal yang dihadapi perusahaan dapat disesuaikan dengan kekuatan dan kelemahan yang dimilikinya. Analisis SWOT ini akan dilakukan pada strategi promosi yang dikeluarkan oleh Hotel Aston Denpasar and Convention Center, Neo Denpasar, Quest Denpasar. Tahapan dalam Analisis SWOT adalah sebagai berikut. Penelitian ini, menggunakan pendekatan penelitian kualitatif yang diitinjau dari jenis data yang digunakan.

\section{HASIL DAN PEMBAHASAN}

Aston Denpasar Berlokasi di jantung kota Denpasar yang berkembang pesat hanya 30 menit berkendara dari bandara Internasional dan dekat dengan area bisnis dan kantor pemerintah pusat. Aston Denpasar menawarkan akses mudah ke semua atraksi utama di Bali Selatan dan sekitarnya termasuk tempat perbelanjaan eksklusif di Bali dan tempat wisata di Ubud, Tanah Lot, Kuta, dan Legian. Kapasitas pertemuan Aston Denpasar memiliki grand ballroom yang dapat menampung hingga 2000 orang; beserta ruang serba guna yang tersedia untuk kapasitas 30-200 orang di ruang Agung, ruang Batukaru, dan ruang Abang yang terletak tepat di lobby area. Dengan tambahan 10 ruang pertemuan di lantai B1, ini akan meningkatkan lebih banyak peluang untuk mendapatkan MICE grup besar dan banyak pilihan bagi tamu kami untuk memenuhi Perhelatan MICE mereka.

Tipe kamar Hotel dengan 3 tipe pilihan kamar. Kamar studio luas $30 \mathrm{~m} 2$ dengan pemandangan kolam renang, One bedroom dengan konsep apartemen $40 \mathrm{~m} 2$ dan dekorasi kota modern dengan ruang tamu terpisah, dan Twobedrooms dengan luas $60 \mathrm{~m} 2$. Area parkir: Hotel memiliki area parkir sendiri di lantai B2 dengan kapasitas 200 mobil. Karena target pasar utamanya adalah MICE, Aston Denpasar memiliki ballroom terbesar ke-2 di Denpasar.

Quest Denpasar Terletak di Pusat kota Denpasar, hotel ini menawarkan kamar suite, bersih dan nyaman yang dirancang secara imajinatif dengan kecanggihan modern dan suasana kontemporer. Quest San Hotel Denpasar ramah dan praktis, menawarkan kombinasi gaya dan fungsi yang luar biasa dilengkapi untuk liburan yang mewah, tetapi lengkap dan menyenangkan bagi wisatawan. Setiap kamar dilengkapi dengan perabotan kontemporer yang apik, TV layar datar, minibar, dan akses Wi-Fi berkecepatan tinggi gratis. Restaurant Bhira dengan menu Bali . Merupakan pilihan pertemuan atau acara khusus untuk kelas bintang tiga. Ballroom yang luas dapat menampung hingga 300 orang, Ideal untuk acara perayaan sosial event. Memiliki 5 ruang pertemuan tambahan untuk mice. Quest Hotels didukung oleh grup manajemen hotel terbaik di Indonesia, Archipelago International. WiFi 
gratis di setiap kamar dan di seluruh properti, seprai dan handuk putih bersih bersih, alas kasur mewah, pancuran air panas, kamar ber-AC yang sejuk, standar ramah lingkungan, dan layanan meja depan 24 jam dengan keramahan Indonesia yang ramah.

Hotel Neo Denpasar adalah lokasi yang ideal untuk memulai perjalanan Anda ke Art Center artistik, Monumen Bajra Sandhi dan Pura Jagatnatha. Terletak hanya 45 menit dari Bandara Internasional Ngurah Rai. Memiliki 112 kamar tamu di 5 lantai. Hotel Neo Denpasar dilengkapi dengan 4 ruang pertemuan, menampung hingga 400 tamu dalam konferensi bergaya teater besar atau dalam sesi ruang rapat kecil. Semua ruang pertemuan ber-AC dan dilengkapi dengan sound system, papan tulis, proyektor dan layar LCD, ditambah akses internet Wi-Fi berkecepatan tinggi. Hotel Neo Denpasar dengan berbagai fasilitas kami termasuk kolam renang luar ruangan dan ruang kesehatan.

Faktor internal ini digunakan untuk mengetahui seberapa besar kekuatan serta kelemahan yang dimiliki oleh Aston Denpasar, Quest Denpasar dan Neo Denpasar. Data internal kekuatan dan kelemahan dianalisa sesuai hasil wawancara mendalam dengan General Manager dan Sales Marketing Manager di hotel lokasi penelitian. Kekuatan diantaranya yaitu: (Strenght) Memberikan informasi promosi (Diskon) produk hotel sesuai harapan konsumen, Karyawan memberikan pelayanan yang baik kepada konsumen, Akses web dan online yang mudah dan praktis, Kebijakan promosi produk yang diberikan perusahaan dapat memberikan kepuasan bagi konsumen, Memberikan harga promosi yang kompetitif. Kelemahan (Weakness) diantaranya Waktu check in kamar saat pandemi Covid 19, Variasi makanan saat pandemi Covid 19, Penawaran Harga antara online dan offline channel saat pandemi Covid 19, Pelayanan service restaurant hotel saat pandemi Covid 19, Fasilitas hotel (kolam renang, gym, taman bermain anak) saat pandemi Covid 19. Sedangkan Faktor Eksternal digunakan untuk mengetahui peluang serta ancaman yang didapat serta dihadapi oleh Aston Denpasar, Quest Denpasar dan Neo Denpasar. Data External peluang dan ancaman dianalisa sesuai hasil wawancara mendalam dengan General Manager dan Sales Marketing Manager di hotel lokasi penelitian untuk Peluang (Opportunities) diantaranya Memberikan informasi promosi produk hotel sesuai harapan konsumen, Karyawan memberikan pelayanan yang baik kepada konsumen, Akses web dan online yang mudah dan praktis, Kebijakan promosi produk yang diberikan perusahaan dapat memberikan kepuasan bagi konsumen, Memberikan harga promosi yang kompetitif. Sedangkan untuk Ancaman (Threats) diantaranya Kebijakan pemerintah dikondisi Covid -19(PSBB, PPKM, PPKM LEVEL), 
Harga Hotel lain yang murah, Konten sangat menentukan dalam Pembatasan kegiatan wedding, beraktivitas di social media atau digital meeting,arisan, wisuda di hotel, Penjualan platform untuk menarik perhatian dan minat online semakin dominan, Tingginya cancel konsumen. Keputusan konsumen tergantung booking selama kondisi Covid 19.

\section{Strategi Bauran Promosi yang} dilakukan oleh Aston Denpasar, Neo

\section{Denpasar, Quest Denpasar dimasa} pandemi covid 19

\section{a. Personal selling}

Dari hasil wawancara, observasi dan dokumentasi personal selling yang dilakukan oleh Hotel Aston Denpasar Hotel Neo Denpasar dan Hotel Quest Denpasar adalah melakukan kontrak tertulis dengan waktu yang ditentukan dengan pemberian harga khusus dan flat selama waktu yang telah tertulis didalam kontrak, tidak akan di pengaruhi oleh seasonable (surcharge). Biasanya kontrak ini berikan kepada travel agent seluruh Indonesia kemudian whole sale agent, overseas agent, perusahaan multinasional, online travel agent serta bank seluruh Indonesia.

b. periklanan

Diantaranya social media advertising berikut contoh Gambar 1: contoh social advertising

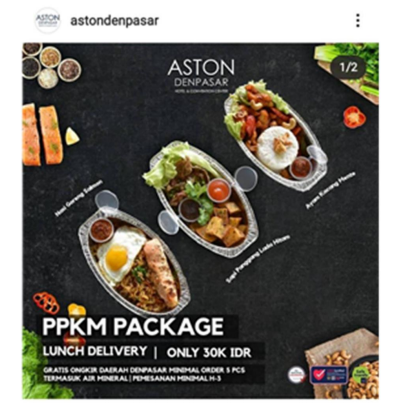

Sumber: Sales and Marketing Aston Denpasar, 2021 pada rating dan komentar yang diberikan secara online. Program iklan food and beverege digital adalah salah satunya via social media seperti facebook, instagram, dan youtube. Salah satu program yang dilakukan disaat pandemi adalah paket ppkm dan paket delivery yang bisa dipesan melalui social media go food dan grabfood Selanjutnya ada website Website dimana ini merupakan konsentrasi yang selalu di kontrol dan dikembangkan oleh tim sales. Karena penjualan secara online melalui websites akan lebih menguntungkan dibandingan penjualan melalui platform kerjasama. Web dan membership biasanya digunkan oleh konsumen yang loyal kepada hotel.

c. promosi penjualan

Special rate dimasa pandemi adalah pemberian diskon dengan rata-rata empat puluh hingga lima puluh persen. Program promosi yang telah dilakukan oleh Aston Denpasar, Neo Denpasar dan Quest Denpasar Program Partnership Special Rate Pada program partnership ini merupakan bentuk kerjasama dengan salah satu bank terbesar di indonesia yaitu Bank BCA, dimana pada kerjasama ini bertujuan untuk menargetkan bagi konsumen BCA dengan memberikan harga khusus ataupun potongan harga 
khusus untuk seluruh grup member archipelago internasional.

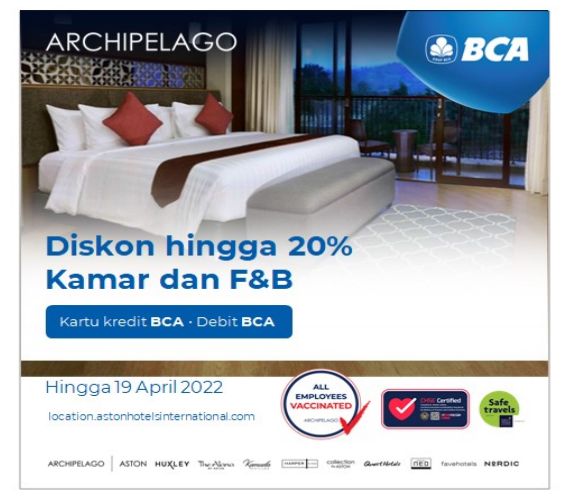

Gambar 2 Program Partnership

Sumber: Sales Marketing Archipelago, 2021

Selanjutnya terdapat program promosi mice platform digital Pada program digital ini mempunyai program platform tersendiri yang dinamakan platform bridestory dimana pada platform ini ditujukan kepada calon pengantin yang sedang mencari tempat acara pernikahan baik itu ditujukan para calon pengantin lokal dan mancanegara. Platform dilengkapi pilihan tempat pernikahan, lokasi, vendor dekorasi, vendor dan cenderamata. Bridestory sangat intens melakukan komunikasi dengan vendor dalam meningkatkan dan membaca target konsumen. Konsumen akan menghubungi pihak bridestory melalui platform dan kemudian akan diemail ke pihak hotel untuk memberikan penawaran paket wedding yang di inginkan oleh klien.

Selanjutnya ada publisitas dimana publisitas adalah upaya yang dilakukan oleh suatu perusahaan agar bisa terlihat lebih dipercaya dan produknya bisa terus diingat oleh masyarakat luas. Upaya publisitas ini yang dilakukan oleh ketiga hotel ini melalui press release, website hotel media sosial.

\section{Strategi Saluran Distribusi yang} dilakukan oleh Hotel Aston Denpasar, Hotel Neo Denpasar, Hotel Quest Denpasar dimasa pandemi Covid 19

Hotel menentukan jalur distribusi terbaik untuk produk produknya guna memenuhi kebutuhan konsumen. Berikut ini pilihan saluran distribusi yang dapat digunakan produsen untuk mencapai konsumen:

Distribusi langsung, Distribusi ini dilakukan langsung dari produsen kepada konsumen tanpa melalui perantara, channel yang digunakan dalam menawarkan atau mempromosikan produk hotel secara langsung, diantaranya adalah tamu yang secara langsung datang membeli produk ke hotel atau disebut walk in guest atau tamu dapat melakukan pembelian melalui Online Travel Agent yang menggunakan traveloka, tiket.com, booking.com, Pegipegi. Distribusi melalui Wholesale agent adalah Wholesale agent travel mendistribusikan produknya untuk kemudian dijual ke grosir, pengecer, atau keduanya. Wholesale agent ini menjual produk hotel dalam jumlah banyak. sehingga harga yang didapatkan akan berbeda dari tamu yang melakukan pembelian langsung. Distribusi melalui Travel agent adalah agent menyalurkan produknya melalui grosir, pengecer dan pembeli industri langsung. 
3. Rekomendasi Strategi Bauran promosi dan strategi saluran distribusi yang tepat dimasa pandemi melalui Swot Analisis

Berdasarkan analisis IE Matrix swot, strategi pemasaran Aston Denpasar, Neo Denpasar dan Quest Denpasar yang bergerak pada bidang Perhotelan, khususnya pada divisi Penjualan berada pada Kuadran II. Strategi pertumbuhan melalui integrasi horizontal ialah dengan cara memperluas lini produk dan saluran distribusinya ke wilayah wilayah potensial lainnya secara intensif. Standar Protokol di Masa Pandemi Covid-19 terutama ketika berbicara mengenai pandemi Covid -19 tentu banyak yang akan dilakukan mengenai awareness bagi para calon tamu ataupun pengantin tersebut dimana pada hotel aston, neo dan quest denpasar telah menambah fasilitas program tersebut dengan tujuan untuk membuat tamu merasa aman dan nyaman ketika melakukan hubungan kerjasama dengan hotel tersebut, seperti CHSE, Vaksin untuk semua karyawan dan MUI. Dibawah ini contoh gambar penerapan dan standar protocol kesehatan yang dilakukan oleh hotel dibawah Archipelago Interantional.

1. All staff telah divaksin

2. Standar jarak meeting sesuai ketentuan SK

Gubernur Prov Bali Tahun 2020

3. Tools yang digunakan saat melayani tamu saat meeting dan makan pagi

4. Keamanan Standar check in

Selain itu dengan terus memantau dan memonitor persaingan harga yang terjadi saat ini. Dengan kontrol harga dan mengetahui pergerakan lawan akan sangat memudahkan kita untuk memutuskan harga yang akan kita tawarkan kepada konsumen. Saat ini sangat banyak platform yang menawarkan intelligent online persaingan bisnis. Di era yang sangat maju akan teknologi diharapkan marketing staff harus mampu mengikuti teknologi dalam meningkatkan keahlian virtual agar dapat memberikan performa maksimal. Ini akan sangat memberikan impact yang besar bagi perusahaan dari sisi pemasukan perusahan.

\section{KESIMPULAN}

Hasil penelitian menunjukkan bahwa (1) Strategi bauran promosi hotel yang dilakukan oleh Hotel Aston Denpasar, Hotel Neo Denpasar, Hotel Quest Denpasar dimasa pandemi Covid 19 telah berjalan dengan baik, dimana strategi yang digunakan pada ketiga hotel tersebut adalah melakukan bauran promosi yang sama yaitu melakukan strategi personal Selling dengan melakukan kontrak tertulis dengan waktu yang ditentukan dengan pemberian harga khusus dan flat selama waktu yang telah tertulis didalam kontrak, tidak akan di pengaruhi oleh seasonable (surcharge). Kemudian Periklanan terdapat penggunaan social media, advertising dan website, selanjutnya publisitas dimana strategi ini menggunakan press release berupa artikel, dan yang terakhir yaitu promosi penjualan dimana strategi ini menggunakan platform bride 
story untuk menarik konsumen pasangan yang ingin menikah, namun diantara masingmasing hotel tersebut memiliki perbedaan pada target konsumen dengan alasan adanya perbedaan klasifikasi bintang, (2) Strategi saluran distribusi yang dilakukan oleh Hotel Aston Denpasar, Neo Denpasar dan Quest Hotel juga berjalan dengan baik dimana hotel tersebut menentukan jalur distribusi terbaik untuk produk produknya guna memenuhi kebutuhan konsumen, diantaranya menggunakan distribusi langsung yang dilakukan langsung dari produsen kepada konsumen tanpa melalui perantara, selanjutnya strategi distribusi melalui Wholesale agent dimana pada strategi ini Wholesale agent travel mendistribusikan produknya untuk kemudian dijual ke grosir, pengecer, atau keduanya. Dan yang terakhir yaitu strategi distribusi melalui Travel agent dimana strategi ini adalah menyalurkan produk melalui grosir, pengecer dan pembeli industri langsung , (3) Rekomendasi strategi bauran promosi dan strategi saluran distribusi yang tepat dilakukan di masa pandemic covid-19 pada hotel Aston yaitu strategi pertumbuhan melalui integrasi horizontal dengan cara memperluas lini produk dan saluran distribusinya ke wilayah wilayah potensial lainnya secara intensif.

Sedangkan untuk strategi bauran promosi dan Saluran Distribusi Hotel Neo Denpasar juga menggunakan strategi pertumbuhan melalui integrasi horizontal dengan cara memperluas lini produk dan saluran distribusi terutama hotel telah memiliki kekuatan potensial di daerah Kota Denpasar dan Kabupaten Buleleng, Kabupaten Jembrana, Kabupaten Badung, Kabupaten Tabanan, Kabupaten Gianyar dan Kabupaten Bangli sehingga harus memanfaatkan potensial lokal dan potensial dari Jawa tengah dan Jawa timur

$$
\text { Selanjutnya strategi bauran }
$$

pemasaran dan distribusi oleh Quest Denpasar yang bergerak pada bidang Perhotelan, khususnya pada divisi Penjualan juga berada pada Kuadran II, dimana strategi ini melakukan strategi pertumbuhan melalui integrasi horizontal ialah dengan cara memperluas lini produk dan saluran distribusinya ke wilayah wilayah potensial lainnya secara intensif

\section{REFERENSI}

Abdullah, Thamrin., and Francis Tantri. 2012. Manajemen Pemasaran. PT Raja Grafindo Persada : Jakarta

Fandy, Tjiptono. 2016. Service, Quality \& satisfaction. Yogyakarta. Andi

Kotler, Philip and Kevin Lane Keller, 2016. Marketing Managemen, 15th Edition, Pearson Education,Inc.

Muhammad jaiz 2014. Dasar-dasar Periklanan. Yogyakarta: Graha Ilmu.

Kotler, Philip dan Gary Amstrong. 2018. Principles of Marketing. Edisi 15 Global Edition. Pearson.

Philip Kotler, dan Kevin Lane Keller, Manajemen Pemasaran, (Jakarta:Indeks, 2009)

Rangkuti, Analisis SWOT Teknik Membedah Kasus Bisnis, (Jakarta: Gramedia Pustaka Utama, 2013) 
Sudaryono. 2016. Manajemen Pemasaran

Teori Dan Implementasi.

Yogyakarta: ANDI

Sugiyono, 2013. Metodelogi Penelitian

Kuantitatif, Kualitatif Dan R\&D.

(Bandung: ALFABETA) 